\title{
1. Environmental impact assessment: introduction to a policy instrument manifesting sustainable development
}

It is generally understood that the first national EIA procedure established was the National Environmental Policy Act (NEPA 1969, as amended) of the United States in 1969. Thereafter, the EIA procedure first spread to the commonwealth countries of Canada and Australia, and then to Europe and also to some developing countries (Gilpin 1995; Harrop and Nixon 1999). International banks like the World Bank or the European Bank for Reconstruction and Development (EBRD) started to make EIA a pre-condition for any loan they gave (Bastmeijer and Koivurova 2008, part 3). At the moment, practically all states have their EIA systems in place (Yang and Percival 2009). Even the transboundary EIA, an extension of domestic EIA to foreign states and other actors has, in the words of the International Court of Justice (ICJ) become

... a practice, which in recent years has gained so much acceptance among States that it may now be considered a requirement under general international law to undertake an environmental impact assessment where there is a risk that the proposed industrial activity may have a significant adverse impact in a transboundary context, in particular, on a shared resource. (Pulp Mills Case 2010, para. 204)

This is no wonder since the EIA procedure is seen as one of the most important means of implementing the goal of sustainable development.

\section{INTRODUCTION TO THE ENVIRONMENTAL IMPACT ASSESSMENT}

There have existed differences between the national EIA procedures since the idea of EIA was implanted into different national traditions of environmental protection (Gilpin 1995, pp.2-4). Yet, certain basic elements of 
a typical EIA procedure can be outlined. An EIA procedure is frequently established either via a separate piece of legislation or by including EIA provisions in existing sectoral laws. The main function of an EIA procedure is to produce scientific information for the decision-making on the proposed activity. In this sense, an EIA procedure is not a procedure leading to a decision, but one producing information for a separate procedure that deals with the actual licensing decision. Frequently, it is provided in national EIA laws and regulations that the licensing decisionmaker is obligated to take into account the results of the EIA procedure.

Importantly, the EIA procedure provides comprehensive information on all potential environmental impacts of the proposed activity. It does not only produce information that studies the potential environmental impact of the proposed activity, it also requires that the potential environmental impact of alternatives to the main plan, including the so-called zero-alternative, in which nothing is constructed, be assessed and possible mitigation measures outlined. The decision-maker is thus provided with information that facilitates its task of prescribing the permit conditions for the proposed activity, not only its task of comparing the costs and benefits of the activity.

Most EIA procedures require that the uncertainty confronted in making the impact studies be explicated. Since the language of the impact studies can be hard to understand, based as it is on scientific terminology, it is normally required that the results of the impact studies be written and presented in such a way that other than experts are also able to understand and assess the potential impact of the proposed activity. Since most EIA procedures require that the public and relevant governmental authorities are entitled to participate in an EIA procedure one way or another, it is important that the results of the impact studies be written in an understandable manner.

A special terminology has developed to describe the different phases of this assessment procedure, called an EIA procedure here. In some jurisdictions, the term describing the whole procedure is environmental assessment (EA) (e.g. in the United Kingdom). Sheate gives a good explanation for why the term EIA is preferable:

This book refers throughout to EIA (environmental impact assessment) although EA (environmental assessment) is used more widely in the EC and the UK. However, EA in the United States of America is used to describe an early assessment of whether an EIA is required. The use of EIA therefore avoids confusion. (Sheate 1996, p. 14)

Because some differences in EIA terminology exist, it is useful to define what is meant by each term used in this book. Not all proposed activities 
go through an EIA procedure. Since only those activities that are known to be environmentally harmful are to be assessed, a decision must be made as to which activities are harmful enough to require an assessment procedure. In some jurisdictions, the preferred system is a mandatory list of activities, normally included in the general legislative act on EIA. These activities have been evaluated as being environmentally harmful in all situations, and therefore require an EIA procedure. In some jurisdictions, no such list exists, and the responsible agency has discretion to decide whether to apply an EIA procedure or not. In most jurisdictions, elements from both of these systems are included. The system by which the state determines those activities that go through the EIA procedure can be called a screening system, whereas a decision to apply the EIA procedure to a certain individual activity can be called the screening phase of an EIA procedure.

As was outlined above, an EIA procedure provides not only information on potential environmental impacts but also all kinds of other information, such as possible mitigation measures. The requirements as to the scope of the studies to be made are normally laid down in a general legislative act, but in some jurisdictions a special scoping procedure must be organized. A scoping procedure is the phase of an EIA procedure in which the public and relevant governmental authorities are entitled to make comments on which issues should be taken up in the assessment studies. Many jurisdictions provide both a list of issues that have to be addressed in the assessment studies and a separate scoping procedure. The document that records the results of the impact studies which have been conducted is called the 'Environmental Impact Statement (EIS)'. The actual EIA procedure is normally undergone with public participation in commenting on the EIS, and the permit decision-maker needs to take all that information into account in its decision-making. In some jurisdictions, the post-project monitoring stage is also part of the EIA, wherein the actual impacts of the project can be compared to those predicted in the EIS.

\section{EIA AS A MANIFESTATION OF THE PRINCIPLES OF SUSTAINABLE DEVELOPMENT}

The still current international environmental law and policy is based on the principles adopted in the Rio Conference on Environment and Development in 1992. The Rio Conference was where the principle of sustainable development became the cornerstone principle of international environmental law. The popularity of EIA as a tool of advancing sustainable development manifests throughout the Rio Declaration, the 
foundational document for international environmental law. Principle 17 of the Declaration speaks directly to the relevance of EIA:

Environmental impact assessment, as a national instrument, shall be undertaken for proposed activities that are likely to have a significant adverse impact on the environment and are subject to a decision of a competent national authority. (Rio Declaration 1992)

Yet, many other ideas that are an integral part of EIAs are endorsed in the Rio Declaration. EIAs apply throughout different sectors of policy and are thus in line with principle 4, which states that 'In order to achieve sustainable development, environmental protection shall constitute an integral part of the development process and cannot be considered in isolation from it'. Principle 10 advances the role of the public in environmental decision-making 'and the opportunity to participate in decision-making processes', which take place also via EIA procedures. It can also be argued that EIA procedures reflect some aspects of the precautionary approach as enshrined in principle 15 of the Rio Declaration, which requires action already before full scientific certainty, since most EIA procedures require that the uncertainty confronted in making the impact studies be explicated.

Aspects of transboundary EIAs are also endorsed in principle 19, whereby origin states are obliged to notify potentially affected states with relevant information, if the proposed activities may have a significant adverse transboundary environmental effect 'and shall consult with those States at an early stage and in good faith'.

According to principle 22:

Indigenous people and their communities and other local communities have a vital role in environmental management and development because of their knowledge and traditional practices. States should recognize and duly support their identity, culture and interests and enable their effective participation in the achievement of sustainable development.

This principle is also of much importance for EIA procedures, as it is normally in these procedures where the traditional knowledge of indigenous and other local communities should play a role, together with their effective participation.

\section{REFERENCES}

Bastmeijer, Kees and Koivurova, Timo (eds) 2008. Theory and Practice of Transboundary Environmental Impact Assessment, monograph series on Legal 
Aspects of Sustainable Development (general series editor David Freestone), Leiden: Martinus Nijhoff.

Gilpin, Alan 1995. Environmental Impact Assessment (EIA): Cutting Edge for the Twenty-First Century, Cambridge: Cambridge University Press.

Harrop, Owen and Nixon, Ashley (eds) 1999. Environmental Assessment in Practice, Routledge Environmental Management Series, Abingdon: Routledge.

NEPA 1969. The National Environmental Policy Act of 1969, as amended, available at: http://energy.gov/sites/prod/files/nepapub/nepa_documents/RedDont/ Req-NEPA.pdf

Pulp Mills Case 2010. Case Concerning Pulp Mills on the River Uruguay (Argentina v. Uruguay), Judgment of 20 April 2010, available at: http://www.icj-cij.org/ docket/files/135/15877.pdf

Rio Declaration 1992. Available at: http://www.un.org/documents/ga/conf151/ aconf15126-1annex1.htm

Sheate, William 1996. Environmental Impact Assessment: Law and Policy; Making an Impact II, London: Cameron May.

Yang, Tseming and Percival, Robert V. 2009. 'The Emergence of Global Environmental Law'. 36 Ecology Law Quarterly 615. 